\title{
EKSISTENSI TANAH ADAT DAN MASALAHNYA TERHADAP PENGUATAN DESA ADAT DI BALI
}

\author{
I Made Suwitra \\ Fakultas Hukum Universitas Warmadewa Denpasar, Bali, Indonesia \\ Email address: madesuwitra27@gmail.com
}

\begin{abstract}
Abstrak
Penulisan ini dimaksudkan untuk memberikan pemahaman bagi Prajuru Desa Adat di Bali terhadap konsepsi dan asas-asas penguasaan dan pemilikan Tanah (Hak) Ulayat yang dikenal dengan Tanah Adat yang tunduk pada hukum adat setelah terbitnya UU No.5 Tahun 1960, yaitu relevan dengan wacana "penguatan Desa Adat". Masalah utamanya adalah menemukenali implikasi pendaftaran hak atas tanah adat yang diorientasikan untuk memperoleh sertipikat hak milik dalam menjamin kepastian hukum. Metode yang digunakan berupa penelitian hukum normatif dan penelitian hukum empiris. Pendekatan masalah menggunakan pendekatan perundang-undangan, analitik, kasus, dan hukum adat. Data primer dikumpulkan melalui observasi, dan data sekunder berupa bahan hukum dikumpulkan dengan teknik dokumentasi dan pencatatan, selanjutnya dianalisis dengan teknik interpretasi dan kualitatif. Tanah (hak) ulayat merupakan salah satu asset Desa Adat yang dapat dimanfaatkan dan digunakan untuk mencapai kesejahteraan bagi warganya dengan melakukan inovasi dalam tata kelola dan terintegrasi dalam perspektif ekowisata sebagai salah model penguatan Desa Adat. Model pendaftaran hak atas tanah adat cukup dilakukan dalam peta dasar pendaftaran tanah. Karena pendaftaran hak melalui penyertipikatan dapat melemahkan posisi tawar Desa Adat terhadap penguasaan hak atas tanah ulayat dan cendrung menjadi tanah komunal. Oleh karena itu diperlukan ketepatan pilihan dalam pendaftarannya.
\end{abstract}

\section{Latar Belakang dan Rumusan Masalah}

Penguatan Desa Adat sebagai Term saat ini merupakan plihan kata untuk mengingatkan seluruh komponen masyrakat Bali terhadap kondisi yang sedang dihadapi, yaitu kompleksitasnya masalah baik dalam skala lokal maupun dalam skala Nasional. Bahkan dalam rapat tim Bintek tanggal 13 Maret 2019 disepakati menggunakan tema "Penguatan Desa Adat melalui Diklat Prajuru Desa Adat Se Bali". Wacana penguatan Desa Adat wajib disambut baik terlepas dari kepentingan, karena penguatan Desa Adat memang dibutuhkan. Namun untuk penguatannya diperlukan pemikiran cerdas dan tanggap, salah satunya melalui pendekatan koeksistensi dari beberapa perspektif, seperti: kelembagaan, penganggaran, program kerja, dan komitmen.

Salah satu pemikiran yang relevan direferensi dalam mengkaji tanah adat terhadap penguatan Desa Adat, yaitu dari pernyataan I Putu Dody Sastrawan dkk, yaitu bahwa: Keberadaaan tanah Druwe Desa menjadi tolak ukur eksistensi dari suatu desa pakraman. Tanah ini juga menjadi filosofi dari unsur Palemahan, yaitu salah satu unsur keseimbangan hidup yang berkaitan langsung dengan lingkungan. Selain itu juga, tanah Druwe Desa merupakan bagian dari pengejawantahan unsur Pawongan dan Parahyangan, yang bersatu-padu dalam mencapai keseimbangan hidup pada suatu desa pakraman[1].

Penguasaan hak atas tanah sering menimbulkan konflik baik secara vertikal 
maupun horizontal. Konflik dibidang penguasaan hak atas tanah ini dapat disebabkan karena beberapa faktor seperti: karena adanya perubahan pola pikir masyarakat dari komunal menuju individualistik, dari komunal religious menuju sekuler individual[2], juga adanya perubahan pemaknaan konsep penguasaan menuju pemilikan, adanya kekeliruan untuk mamaknai konsep yang digunakan dalam UUPA dengan konsep yang mereka warisi secara turun temurun. Juga secara umum dapat dinyatakan, bahwa sengketa tanah terjadi karena ada perubahan nilai ekonomi dari tanah itu sendiri yang kian meningkat[3].

Meningkatnya nilai ekonomi tanah secara signifikan terjadi di daerah perkotaan, seperti Kota Denpasar yakni yang disebabkan adanya peningkatan jumlah penduduk yang berdampak pada meningkatkan kebutuhan akan tanah terutama untuk perumahan, area untuk melakukan tempat berbagai usaha bisnis dari yang berskala kecil sampai yang berskala besar. Dalam kondisi ini, awalnya banyak kalangan masyarakat yang menjual tanahnya karena tergiur harga mahal dan keinginan ingin cepat punya uang banyak tanpa diikuti dengan usaha dan kerja keras. Semua itu hanya untuk memenuhi kebutuhan materiil dan memuaskan keinginan secara pragmatis.

Peralihan penguasaan hak atas tanah menjadi pemilikan yang sedemikian tinggi, mengakibatkan munculnya daerahdaerah permukiman baru di daerah persawahan (subak) yang berdampingan dengan masyarakat adat. Sampai saat ini di beberapa subak di Kota Denpasar secara legal terjadi alih fungsi terhadap tanahtanah pertanian menjadi tanah perumahan seperti di Subak Renon melalui proyek land consolidation (LC), Subak Gatsu dengan dibukanya jalan by pas Gaksu, LC Gatsu Tengah di jalan Bedahulu, LC Gatsu
Timur, Subak Buaji ( Buaji Sari, Buaji Anyar).

Konflik sebagai akibat adanya pemindahan hak atas tanah dapat terjadi terhadap tanah-tanah yang awalnya dikuasai menurut hukum adat dan kemudian dikonversi menurut UUPA[4]. Tanah-tanah tersebut di Bali dikenal dengan tanah adat dalam berbagai jenisnya, yaitu tanah yang dikusai secara komunal seperti: laba pura, laba banjar, laba desa (adat), tanah setra, tanah pasar, tanah lapang dan tanah yang dikusai secara individual seperti tanah pekarangan desa (PKD), tanah ayahan desa (AYDS)[5].

Bali sampai saat ini masih sarat dengan konflik terhadap klaim pemilikan hak atas tanah. Meningkatnya konflik oleh sosiolog Paulus Wirutomo dinyatakan karena pengaruh struktur, kultur, dan proses[6]. Struktur berkaitan dengan kebijakan yang diputuskan pemerintah, atau kebijakan dari kepala atau pemimpin masyarakat (adat), sedangkan kultur menyangkut nilai, norma, dan kepercayaan yang diyakini turun temurun. Untuk meminimalisasi konflik, yang masih bisa diubah hanya sisi proses, karena sisi ini memberikan dinamika interaksi sehari-hari yang memberi ruang bebas dari ikatan struktur dan kultur.

Lebih lanjut diungkapkan, bahwa struktur dinyatakan seringkali dirusak oleh globalisasi dan kepentingan ekonomi. Struktur pemerintahan pun turut membenturkan kultur, seperti keputusan pengadilan yang bertentangan dengan aturan adat. Oleh karena itu diperlukan komunikasi dan negosiasi proses yang menjembatani, baik itu dari dominasi struktur maupun kultur.

Agama adalah tuntunan hidup. Dalam prakteknya ajaran agama (Hindu) berimplementasi ke dalam adat dan budaya Bali. Namun implementasinya sering menimbulkan disharmoni akibat 
dimanipulasi untuk tujuan-tujuan tertentu. Akibatnya marak terjadi konflik adat, praktek budaya anarkis atau frustrasi massal sebagai suatu fakta sosial. Di sisi lain frustrasi masyarakat yang kerap kali tercetus sebagai aksi-aksi kekerasan memerlukan contoh perilaku dan keteladanan saat ini kian langka, sehingga agama, adat, dan budaya dianggap tidak berperan sebagaimana mestinya dan dalam beberapa kasus, bahkan dapat memperburuk kejiwaan masyarakat[7]. Kadang-kadang adat dijadikan alat menjustifikasi anarkisme.

Berlakunya Permen ATR 10/2016 jo Kepmen ATR 276/2017 mempunyai beberapa implikasi terhadap tanah ulayat di Bali, yaitu seperti dinyatakan Suwitra: "That is also intended to protect the existence of Ulayat Land of Pakraman Village, but on the contrary that the appointment of Pakraman Village as a subject that can carry out communal ownership of land, which normatively can be interpreted that there can be a weakening of Ulayat Land status into a Communal Land, even with PTSL as Ulayat land which is individually will be converted into individual property rights according to UUPA which resulted in the extinction of Ulayat land intended[8] (Berlakunya Kepmen ATR No. 276 tahun 2017 memberikan penegasan kembali terhadap pengakuan negara kepada keberadaan masyarakat hukum adat terutama Desa Pakraman di Bali dan sekaligus menunjuk sebagai subjek hak yang dapat memilki hak Pemilikan Bersama (Komunal) atas Tanah dengan beberapa klausula. Namun demikian secara hirarkhi perundang-undangan tidak memenuhi syarat kepastian hukum karena bertentangan atau duplikasi dengan maksud ketentuan Pasal 2 ayat (4) UUPA). Oleh karena itu Kepmen ATR No.276 tahun 2017 tidak mempunyai kekuatan berlaku).
Dari berbagai beberapa pernyataan tersebut di atas, problem kajian yang relevan di bahas adalah menemukan model pendaftaran Tanah (Hak) Ulayat di Bali dalam penguatan Desa Adat dengan berbagai masalahnya.

\section{Metode Penelitian}

Jenis penelitian yang digunakan adalah penelitian hukum normative dan penelitian hukum empiris, karena di satu sisi disinyalir adanya duplikasi norma yang ada dalam Kepmen 276 tahun 2017 dengan UUPA. Akibatnya terjadi kesenjangan juga, yaitu penunjukan Desa Pakraman di Provinsi Bali sebagai subjek hak pemilikan bersama (komunal) atas tanah, berimplikasi melemahkan status tanah (hak) ulayat menjadi tanah komunal. Juga ada tendensi bahwa Desa Pakraman menjadi pemilik hak ulayat yang bertentangan dengan konsep komunal religius dalam penguasaan tanah ulayat.

Pendekatan masalah yang digunakan berupa pendekatan perundangundangan[9], artinya dengan memerhatikan legislasi dan regulasi serta hierarki peraturan perundang-undangan dibidang agraria. Selain itu juga dipergunakan pendekatan konsep, yaitu yang beranjak dari berbagai pandangan dan doktrin yang berkembang di dalam ilmu hukum[9]. Dan pendekatan analitik, yaitu untuk mengetahui makna yang dikandung oleh istilah-istilah yang digunakan dalam aturan perundang-undangan secara tekstual, sekaligus mengetahui kontekstualnya terutama dalam penerapannya melalui praktek dan putusan-putusan hukum[10].

Sumber data diperoleh dari sumber pertama (data primer) dan dari sumber kedua (data sekunder) yang disebut bahan hukum, yaitu berupa bahan hukum primer seperti UUPA, Permen ATR, Kemen ATR. Juga bahan hukum sekunder seperti buku teks, jurnal. Data ini kemudian dianalisis 
dengan teknik hermenetik atau interpretasi dan kualitatif.

\section{Eksistensi Tanah Ulayat dan Tanah Adat di Bali}

\section{a. Konsep Tanah Ulayat dan Tanah Adat}

Hukum adat memandang hubungan antara masyarakat hukum adat dengan tanah yang diduduki mempunyai makna tersendiri. Menurut Hukum Adat, hubungan antara masyarakat hukum adat dengan tanah yang diduduki demikian erat dan bersifat religio magis. Konsekuensinya masyarakat hukum adat memperoleh hak untuk menguasai tanah dimaksud, memanfaatkan tanah itu, memungut hasil dari tumbuh-tumbuhan yang hidup di atas tanah itu, juga berburu binatang-binatang yang hidup di situ. Hak masyarakat hukum adat atas tanah ini oleh van Vollenhoven disebut "beschikkingsrecht" yang kemudian diterjemahkan menjadi hak ulayat atau hak pertuanan.

Hak Ulayat dapat dirumuskan sebagai kewenangan yang menurut hukum adat dipunyai oleh masyarakat hukum adat tertentu atas wilayah tertentu yang merupakan lingkungan para warganya untuk mengambil manfaat dari sumber daya alam, termasuk tanah, dalam wilayah tersebut, bagi kelangsungan hidup dan kehidupannya, yang timbul dari hubungan secara lahiriah dan batiniah turun temurun dan tidak terputus antara masyarakat hukum adat tersebut dengan wilayah yang bersangkutan. Di Bali dikenal dengan istilah hak prabumian[11]. Istilah prabumian ini dapat lihat dalam salinan "Pemuder Desa Adat Culik" sebagai prasasti yang diberikan (Panugrahan) Ida Batarane Ida nak Agung Made Ngurah Karangsem kepada I Pasek Culik yang disalin pada hari Rabu Umanis Wuku Tambir Panglong ping 15 Tileming sasih Ketiga Tahun 1922, yaitu dalam penunjukan penguasaan dan batas-batas
Tanah Bukti Pura Puseh Desa Culik[12]. Tanah bukti Pura ini kemudian dikenal dengan istilah Laba Pura sebagai bagian dari tanah ulayat atau tanah adat.

Pasal 1 ayat (2) Peraturan Menteri Negara Agraria/Kepala Badan Pertanahan Nasional Nomor 5 Tahun 1999 tentang Pedoman Penyelesaian Masalah Hak Ulayat Masyarakat Hukum Adat menyebutkan, bahwa:

Tanah ulayat adalah bidang tanah yang di atasnya terdapat hak ulayat dari suatu masyarakat hukum adat tertentu;

Munculnya istilah tanah adat tidak dapat dilepaskan dari sejarah hukum yang pernah ada, artinya dengan berlakunya dua sistem hukum yang pernah berlaku di Indonesia dan selanjutnya menjadi dasar bagi hukum pertanahan sebelum dibentuknya UUPA, yaitu hukum adat dan hukum Barat[13]. Sehingga ada dua macam tanah, yaitu "Tanah Adat" yang biasa disebut "Tanah Indonesia" dan "Tanah Barat" yang biasa disebut "Tanah Eropa".

Tanah adat dapat dirumuskan sebagai tanah-tanah milik persekutuan, kaum, suku, marga, desa dan sebagainya yang sama sekali bukan milik perorangan, walaupun yang bersangkutan telah memanfaatkan bagi kelangsungan hidupnya[14]. Di lain pihak Valerine Jaqueline Leonoere Kriekhoff menyatakan, bahwa tanah adat dapat diartikan sebagai tanah yang di atasnya berlaku aturan-aturan adat[15].

Saat berlakunya Hukum Agraria di Hindia Belanda (Indonesia), ditemukan adanya lima perangkat hukum, yaitu Hukum Agraria Adat, Hukum Agraria Barat, Hukum Agraria Administratif, Hukum Agraria Swapraja, Hukum Agraria Antar Golongan.

Hukum Agraria Adat dirumuskan sebagai keseluruhan dari kaidah Hukum Agraria yang bersumber pada hukum adat dan berlaku terhadap tanah-tanah yang 
dipunyai dengan hak-hak atas tanah yang diatur oleh Hukum Adat, yang selanjutnya sering disebut tanah adat atau tanah Indonesia.

Hukum Agraria Adat ini terdapat dalam Hukum Adat tentang tanah dan air (bersifat intern), yang memberikan pengaturan bagi sebagian terbesar tanah dalam negara. Diberlakukan bagi tanahtanah yang tunduk pada hukum adat, seperti tanah (hak) ulayat, tanah milik perseorangan yang tunduk pada hukum adat[16]. Jadi Tanah Adat (tanah druwe desa) dapat disamakaan dengan tanah (hak) ulayat.

Apabila hak atas tanah adat berada pada sekelompok orang dan diatur pemanfaatannya oleh pimpinan dari kelompok, maka hak bersama tersebut dikenal dengan hak ulayat. Jadi tanah ulayat sama dengan tanah adat.Aturanaturan adat atau hukum adat mempunyai kategori yang berbeda dengan adat belaka. Menurut L Pospisil, menyebutkan adanya empat atribut hukum, yaitu: The attribute of authority, The attribute of intention of universal application, The attribute of obligation, The attribute of sanction[17].

\section{b. Tanah Adat dan Realitas Penguasaannya}

Hukum adat memandang kehidupan individu sebagai kehidupan yang terutama diperuntukkan buat mengabdi kepada masyarakat. Berdasarkan konsepsi tersebut, tanah ulayat sebagai hak kepunyaan bersama dari suatu masyarakat hukum adat dipandang sebagai tanah bersama yang merupakan "pemberian/anugerah" dari suatu kekuatan gaib, bukan dipandang sebagai sesuatu yang diperoleh secara kebetulan atau karena kekuatan daya upaya masyarakat adat tersebut. Jadi hak ulayat yang menjadi lingkungan pemberi kehidupan bagi masyarakat adat dipandang sebagai tanah bersama, sehingga semua hak perorangan bersumber dari tanah bersama tersebut[18].

Pernyataan di atas relevan dengan teori hak milik menurut paham hukum kodrat dari Grotius yang menyatakan, bahwa segala sesuatu dalam alam sebagai milik bersama. Alam atau dunia ada untuk digunakan secara bersama-sama oleh umat manusia. Hak milik pribadi hanya diterima dalam pengertian hak untuk menggunakan milik bersama. Jika seseorang dikatakan memiliki sesuatu, tidak lain artinya ia mempunyai kemampuan untuk menggunakan secara tepat milik bersama, dan bukan menjadi miliknya sedemikian rupa yang menutup kemungkinan dimiliki individu lain[18].

Menurut Laporan Penelitian Integrasi Hak Ulayat ke dalam Yurisdiksi UUPA, Depdagri-FH UGM Tahun 1978 dinyatakan, bahwa hak ulayat sebagai istilah teknis yuridis adalah hak yang melekat sebagai kompetensi khas pada masyarakat hukum adat, berupa wewenang/kekuasaan mengurus dan mengatur tanah seisinya dengan daya laku ke dalam maupun ke luar[19].

Masyarakat hukum adat merupakan kesatuan masyarakat adat yang bersifat otonom di mana mereka mengatur sistem kehidupannya (hukum, politik, ekonomi dan sebagainya), selain itu bersifat otohton, yaitu suatu kesatuan masyarakat hukum adat yang lahir/dibentuk oleh masyarakat itu sendiri, bukan dibentuk oleh kekuatan lain, misalnya kesatuan desa dengan LKMDnya. Sekarang tidak lagi sepenuhnya otonom dan terlepas dari proses pengintegrasian ke dalam kesatuan organisasi kehidupan negara bangsa yang berskala besar dan berformat nasional[19].

Sebagai isi wewenang dari hak ulayat dimaksud, maka hubungan antara masyarakat hukum adat dan tanah/wilayahnya adalah hubungan menguasai[18], bukan hubungan milik 
sebagaimana halnya dalam konsep hubungan antara negara dengan tanah, menurut Pasal 33 Ayat (3) UUD NRI Tahun 1945[21].

Penentuan masih ada atau tidaknya hak ulayat, dapat menggunakan tiga kriteria, seperti di bawah ini, yaitu:

(1) Adanya masyarakat hukum adat yang memenuhi ciri-ciri tertentu sebagai subjek hak ulayat;

(2) Adanya tanah/wilayah dengan batasbatas tertentu sebagai Lebensraum yang merupakan objek hak ulayat; dan

(3) Adanya kewenangan masyarakat hukum adat untuk melakukan tindakantindakan tertentu sebagaimana telah diuraikan di atas[19].

Berdasarkan pemahaman dan konseptual tersebut di atas, maka diferensiasi Hak Penguasaan Atas Tanah (HPAT) menurut hukum adat terdiri dari: Hak Ulayat (hak komunal) dan hak-hak individu atas tanah[20]. Hak ulayat merupakan HPAT yang tertinggi dalam hukum adat. Dari hak ulayat, karena proses individualisasi dapat lahir hak-hak perorangan (hak individu). Adalah relevan dengan pernyataan Achmad Sodiki, bahwa: Sistem penguasaan tanah dalam hukum adat adalah berdasar hak ulayat, yaitu suatu hak masyarakat hukum sebagai suatu kesatuan yang mempunyai wewenang ke luar dan ke dalam. Artinya dalam hak ulayat ini terdapat hak perseorangan (individual) atas tanah, yakni hak yang lahir karena pengusahaan yang terus menerus secara intensif atas sebidang tanah (kosong)[22].

Lebih lanjut dinyatakan, bahwa hubungan antara hak ulayat (yang dimiliki oleh masyarakat hukum sebagai suatu kesatuan) dengan hak individu merupakan hubungan yang lentur, fleksibel, artinya semakin kuat hak individu atas tanah maka semakin lemah daya berlakunya hak ulayat atas tanah tersebut. Sebaliknya semakin lemah hak individu maka semakin kuatlah daya berlakunya hak ulayat. Hak individu ini akan lenyap dan tanah akan kembali dalam kekuasaan hak ulayat jika tanah ditelantarkan/menjadi belukar atau hutan kembali. Adalah relevan dengan Teori Balon (Ballen Theorie) dari Ter Haar, yang menyatakan bahwa semakin kuat hak ulayat, maka semakin lemah hak perorangan dan demikian sebaliknya[23]. Demikian juga Iman Sudiyat menyatakan, bahwa hak-hak persekutuan dan hak-hak perorangan setiap anggotanya saling mempengaruhi, artinya ada dalam hubungan kempis-mengembang, mulurmungkret tiada henti[24].

Herman Soesang Obeng menyatakan, bahwa untuk memperoleh gambaran yang jelas tentang pemilikan tanah secara perorangan, perlu diperhatikan jalinan timbal balik hubungan hak masyarakat dan hak individu menurut alam pikiran masyarakat adat (participerend denken menurut Ter Haar). Menurut jalinan pemikiran ini, hubungan manusia dengan tanah merupakan hubungan magis religius yang sedikit banyak mengandung unsur kekuatan gaib (mistik) sebagai suatu perwujudan daripada dialog antara manusia dengan alam gaib, yaitu roh-roh yang dihargainya[18]. Oleh karenanya masyarakat akan mengembangkan sejumlah norma-norma tertentu tentang tanah baik yang dikuasai masyarakat maupun secara perorangan. IB. Lasem dalam hubungan dengan penguasaan ini juga menyatakan, bahwa tanah-tanah adat seperti PKD yang dikuasai secara individu di dalamnya terkandung konsep Tri Hita Karana, yaitu berupa Parhyangan yang berwujud Merajan (believe system), Pelemahan yang berwujud wilayah perumahan (artefact system), dan Pawongan yang berwujud anggota keluarga yang tinggal di situ (social 
system) yang notabene sebagai krama banjar dan krama desa adat. Semuanya ini sudah barang tentu diatur dalam awigawig[26].

Tanah-tanah adat ini masih diyakini mempunyai sifat yang religio magis, sehingga kehidupan krama desa diperuntukkan untuk mengabdi kepada Tuhan yang berstana di setiap Pura Kahyangan Tiga dan pura lain yang diempon oleh krama desa yang ada di wilayah desa adat. Kondisi ini tidak terlepas dari perspektif historis yang melatarbelakangi munculnya desa adat menurut isi cerita dalam Lontar Markandya Purana.

Beberapa sifat yang menonjol tentang pemilikan secara individu menurut hukum adat antara lain:

a. Pemilikan tanah hanya dapat dipunyai oleh warga masyarakat hukum saja.

b. Pemilikan tidak lahir berdasarkan keputusan atau izin kepala adat. Keputusan atau izin kepala adat hanya berfungsi sebagai pembuka jalan ke arah kemungkinan menguasai tanah dengan hak milik. Pemilikan lahir berdasarkan pengakuan masyarakat yang disebabkan oleh kenyataan erat tidaknya hubungan seseorang atas tanah. Erat dalam arti tanah senantiasa dikerjakan, dirawat dengan baik dan tidak diabaikan.

c. Pemilikan hanya timbul apabila syarat de facto berupa bertempat tinggal dalam masyarakat hukum, mengerjakan tanah secara terus menerus, dan syarat de jure berupa pengakuan masyarakat akan pemilikan tersebut, berlaku secara bersamaan dalam diri pribadi yang bersangkutan.

d. Berakhirnya hak milik atas tanah, berarti berhentinya pengakuan masyarakat atas hak orang yang bersangkutan[18].
Memahami hubungan penguasaan tanah dalam desa tradisional, konseptual "beschikkingrecht" dari van Vollenhoven sangat membantu. Dua unsur utama yang memberikan ciri khas hak ini yakni, pertama: tiadanya kekuasaan untuk memindahkan tanah, dan kedua, terdapat interaksi antara hak komunal dan hak individu yang mempunyai akibat atau berlaku ke dalam maupun berlaku ke luar[27].

Berakibat atau berlaku ke dalam artinya pertama, persekutuan dan anggotaanggotanya dapat menarik keuntungan dari tanah dan segala yang tumbuh serta hidup di atas tanah itu seperti: mengolah tanah itu, mendirikan tempat tinggal, menggembala ternak, mengumpulkan bahan makanan, berburu, memancing. Jadi hak ini hanya sebatas dipergunakan untuk memperoleh keperluan hidup keluarga dan dirinya sendiri, dan bukan untuk membentuk persediaan keperluan perdagangan (bisnis). Kedua, hak-hak perorangan itu tetap tunduk kepada hak masyarakat (hak ulayat) atas tanah ulayat tersebut, karena masih tetap ada campur tangan persekutuan (masyarakat hukum adat dalam konsep penulis) terhadap pemakaian dan pemindahan hak-hak perorangan itu. Ketiga, Persekutuan dapat menetapkan atau menyediakan tanah itu untuk keperluan umum, seperti untuk kuburan (setra), sekolah, tempat ibadah (pura), pasar, tanah jabatan (bengkok), di Bali dikenal dengan istilah tanah bukti/catu.

Berakibat atau berlaku ke luar artinya ada larangan bagi orang luar persekutuan untuk menarik keuntungan dari tanah ulayat, kecuali ada izin dan sudah membayar uang pengakuan (recognitie). Ketentuan ini berlaku bagi anggota persekutuan jika ia dalam menarik keuntungan terhadap tanah ulayat itu digunakan untuk keperluan dagang (bisnis). 
Kedua, larangan, pembatasan atau berbagai peraturan yang mengikat terhadap orangorang untuk mendapatkan hak perorangan atas tanah pertanian. Artinya orang luar jika akan mengolah tanah persekutuan hanya diberikan hak menikmati (genotrecht) dalam satu kali panen, mereka tidak boleh menjadi ahli waris, atau membeli tanah. Jadi hanya memperoleh kesempatan untuk turut serta menggunakan tanah wilayah persekutuan.

Di Bali hak penguasaan tanah juga dilandasi oleh hak ulayat atau hak prabumian. Kondisi ini akan sangat relevan jika dikaitkan antara hubungan terjadinya desa adat dan tanah adat dalam perspektif sejarahnya. Di samping itu relevan juga dengan teori hukum alam dan accupatio dalam arti adanya penguasaan dan pemilikan bersama (komunal) dan juga penguasaan dan pemilikan secara individual (perseorangan). Hubungan antara hak komunal dengan hak individual juga nampak saling mendesak, menebal dan menipis, mulur-mungkret. Bahkan lebih didominasi oleh hak individual, terutama dalam pemanfaatan tanah pekarangan beserta telajakannya[28]. Proses menebal dan menipisnya hubungan hak komunal dengan hak individu itu nampaknya sangat bergantung pada kepekaan prajuru adatnya dan kesadaran krama desa terhadap tanah-tanah adat yang dikuasainya dalam menentukan apakah hak milik komunal akan berubah statusnya menjadi hak milik individu penuh. Tanah yang dulunya termasuk tanah adat ada kalanya sudah dialihkan menjadi hak milik pribadi penuh yang lebih dikenal dengan tanah Sertifikat Hak Milik (SHM), seperti tanah AYDS yang ada di Desa Adat Kemenuh Gianyar setelah kemerdekaan beralih menjadi tanah individu penuh, sebagai akibat dikeluarkannya surat pajak oleh pemerintah, padahal awalnya AYDS merupakan satu kesatuan dengan tanah PKD.

\section{c. Bagan Penguasaan Tanah Adat di Bali}

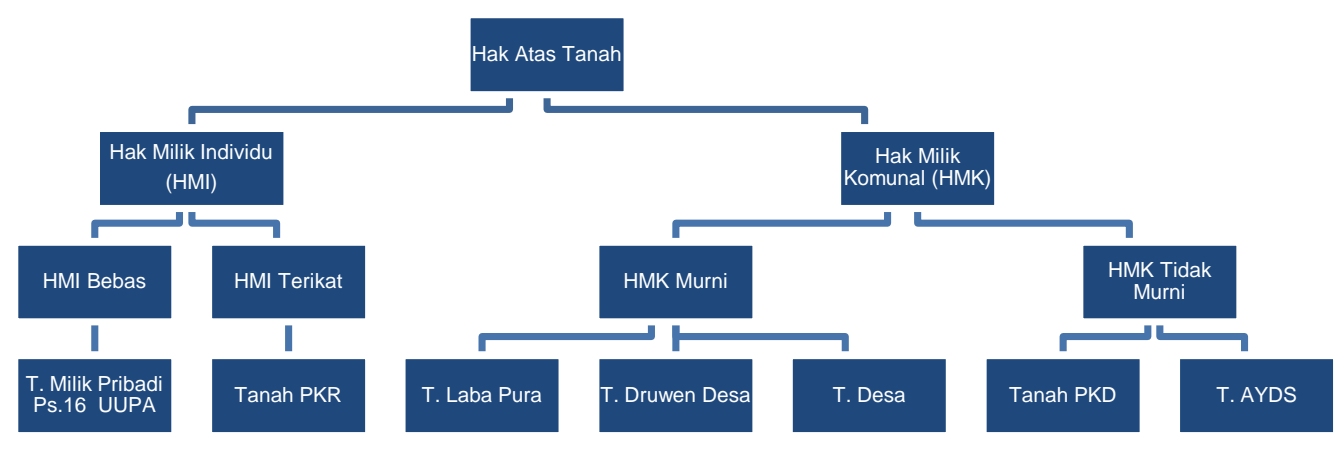

\section{Pendaftaran Tanah Adat dan Permasalahannya}

Sengketa tanah dengan objek tanah-tanah adat sampai saat ini masih dapat dijumpai di Bali. Dari hasil amatan dapat dinyatakan bahwa terjadinya sengketa disebabkan karena bebarapa hal, yaitu: klaim batas desa (Macang-Ngis Karangasem), klaim atas penguasaan setra (Semana-Ambengan Gianyar), klaim atas tanah desa (AYDS, PKD) yang sudah disertipiaktkan melalui konversi (Panji Buleleng, Tusan Klungkung, Tamanbali Bangli), klaim atas tanah laba Pura Desa 
yang telah disertipikatkan atas nama Dadia/perorangan (Culik Karangasem, Kubutambahan Buleleng, Tianyar Karangasem), investasi di atas tanah Laba Pura (Kusumasari Sanur Denpasar), investasi di atas tanah setra (Banjar Ancak Bungkulan Sawan Buleleng), pengingkaran terhadap jual beli tanah PKD (Kemenuh Gianyar), klaim investor atas HGB di atas tanah (hak) ulayat (Loloan Yeh Poh Canggu Badung).

Klaim-klaim atas sebidang tanah adat dan sengketa hak penguasaan atas tanah adat merupakan implikasi atas pendaftarannya menurut hukum Negara (UUPA dan aturan organiknya), yang mengakibatkan adanya peningkatan hak, yaitu dari hak penguasaan (komunal) menjadi pemilikan melalui konversi atau PRONA yang saat ini dikenal dengan PTSL.

UUPA dengan aturan organiknya yang mengusung "kepastian hukum" mempunyai Misi pendaftaran terhadap semua bidang tanah di Indonesia. Jalan yang diberikan adalah "Konversi", yaitu pendaftaran untuk pertama kalinya secara sporadik atau sistematik terutama terhadap tanah-tanah yang telah dikuasai secara perorangan lebih dari 20 tahun berturut turut dengan tidak memilah antara tanah pribadi penuh dengan tanah pribadi tidak penuh seperti tanah PKD, AYDS.

Dalam penelitian Disertasi dinyatakan, bahwa tanah-tanah AYDS dan PKD yang telah dikonvsersi secara masal yang dikenal dengan PRONA terjadi di beberapa desa, seperti di Desa Tamanbali Bangli, Desa Ngis Karangasem[26]. Tujuannya adalah untuk menguatkan eksistensi tanah adat. Namun yang terjadi adalah sebaliknya, yaitu melemahkan status tanah adat sebagai ulayat desa, karena secara konseptual tanah-tanah adat (PKD, AYDS) setelah disertipikatkan tidak lagi berstatus sebagai tanah adat, karena sudah ditundukkan pada hukum Negara di bawah pemilikan individual, sehingga beraspek perdata. Secara jurudis terjadi penguatan hak penguasaan menjadi hak milik individu penuh yang tidak lagi tunduk pada hukum adat (Awig-Awig).

Perubahan status hak atas tanah PKD dan AYDS menjadi hak milik individu penuh setelah disertipikatkan tidak serta merta dapat disadari adanya, dimana sebagian masyarakat dan prajuru adat masih menganggap tanah-tanah tersebut sebagai tanah adat. Sengketa baru terjadi ketika ada peralihan hak kepada pihak lain baik melalui jual beli maupun karena pelelangan oleh Bank atas tanah yang telah dipasang Hak Tanggungan (HT), seperti kasus "Tanah Panji".

Akibat dari perbuatan hukum penyertipikatan tanah-tanah adat yaitu: di satu sisi terjadi penguatan hak pemilikan individu, dan di sisi lain terjadi semakin lemahnya kedudukan Desa Adat atas penguasaan tanah-tanah adat dimaksud, yaitu relevan dengan teori Ballon Ter Haar atau Mulur Mungkretnya Iman Sudiyat. Kondisi ini tidak bisa dibiarkan berlanjut, tapi segera diakukan penyikapan oleh masyarakat hukum adat (Desa Adat) walaupun sudah terlambat.

Sikap terlambat ini diamati sebagai akibat adanya kegamangan pengetahuan Prajuru Adat atas ilmu Hukum Agraria dan Hukum Adat. Akibat lebih jauh adalah ada pembiaran terhadap berbagai pelanggaran atas pemanfaatan dan penggunaan tanahtanah adat yang ada di masing-masing Desa Adat, seperti dibiarkannya alih fungsi tanah telajakan yang dipergunakan sebagai bangunan warung, garase, tempat barang dagangan, bengkel, jualan. Jadi tata ruang Desa Adat tidak lagi merefleksikan falsafah Tri Hitakarana. Kondisi ini membuktikan bahwa Prajuru Adat melakukan pembiaran terhadap alih fungsi tanah-tanah adat, bahkan membiarkan adanya perbuatan- 
perbuatan hukum tanah-tanah adatnya untuk disertifikasi menjadi hak milik individu penuh.

Dalam perspektif kewenangan yang dilandasi hak ulayat, Desa Adat melalui Prajuru Adatnya mempunyai kewenangan untuk mengatur, mengurus, mengelola, dan melakukan pengawasan terhadap hak ulayat sebagai kepunyaan bersama mengenai:

a. peruntukan, penggunaan, persediaan, dan pemeliharaan Hak Ulayat;

b. hubungan hukum antara orang dengan Hak Ulayat; dan

c. hubungan hukum antara orang dan perbuatan hukum yang mengenai Hak Ulayat.

Saat ini kewenangan yang dimiliki Desa Adat tidak dilakukan dengan baik dan benar terutama dalam melakukan pengurusan terhadap peruntukan tanahtanah adat yang masih ada, melakukan pengawasan terhadap penggunaan dan pemanfaatannya, dan melakukan tindakan penertiban terhadap para pelanggar tata ruang Desa Adat, termasuk terhadap penelantaran tanah-tanah adat. Jadai dalam konteks sistem hukum, pengawasan dan penegakan hukum terhadap para pelanggar menjadi taruhan terhadap kuatnya tanahtanah adat di atas penguasaan Desa Adat atau krama Desa Adat.

Terbitnya Permen ATR/Ka.BPN No. 276/KEP-19.2/X/2017 tentang Penunjukan Desa Pakraman di Provinsi Bali Sebagai Subjek Hak pemilikan Bersama (Komunal) Atas Tanah di satu sisi dapat menguatkan hak atas penguasaan dan pemilikan tanah adatnya. Sedang di sisi lain dapat juga melemahkan kewenangan Desa Adat atas tanah ulayatnya ketika salah melakukan pilihan terhadap model pendaftarannya. Kondisi pilihan ini akan bertambah krodit dengan terbitnya Permen ATR/Ka.BPN No. 12 Tahun 2017 dan yang telah diganti dengan Permen ATR/Ka.BPN
No. 6 Tahun 2018 tentang Pendaftaran Tanah Sistematik Lengkap (PTSL) jo Inpres RI No.2 Tahun 2018 tentang Percepatan PTSL di Seluruh Wilayah RI.

Program PTSL yang berorientasi target sebagai indikator keberhasilan tidak menjadikan bidang tanah ulayat menjadi "badai" jilid II (kedua) saat diterbitkannya kebijakan pendaftaran bidang tanah melalui Proyek Operasi Nasional Agraria Nasional (PRONA) yang diatur dalam Keputusan Menteri Dalam Negeri (Kepmendagri) No. 189 Tahun 1981 yang tujuan utamanya memproses penyertipikatan tanah secara masal sebagai perwujudan program Catur Tertib di bidang Pertanahan yang pelaksanaannya dilakukan secara terpadu terutama kepada masyarakat golongan ekonomi lemah, serta menyelesaikan secara tuntas terhadap sengketa-sengketa tanah yang bersifat strategis. Namun diberikan tafsir dan pemberlakuan yang sama antar tanah pribadi dengan tanah-tanah (hak) ulayat Desa Adat. Konsekueinsinya menimbulkan banyak sengketa bahkan sampai saat ini diwariskan.

\section{Penguatan Desa Adat}

Penguatan yang dimaksudkan adalah upaya dalam membekali kompetensi diri berdasar kewenangan yang dimiliki dalam menggunakan dan memanfaatan potensi diri dalam mengelola tanah (hak) ulayat sesuai perundang-undangan yang berlaku. Jadi penguatan Desa Adat dapat berupa pembekalan terhadap kompetensi SDM Desa Adat, Tata Kelola Desa Adat, sumber daya alam dan sumber daya anggaran (pendanaan).

SDM Desa Adat menjadi yang utama dalam penguatan Desa Adat seperti dengan pemberian beasiswa untuk mengikuti pendidikan formal yang lebih tinggi atau sertipikasi profesi sebagai pengawas, badan pemeriksa keuangan LPD, pimpinan atau staf bidang usaha, 
Kepala BUMDes/BUPDA, guide lokal, pengurus LPD, Serati, Jero Mangku, IT, wirausaha rumahan yang mampu mengali dan mengembangkan potensi lokal secara terintegrasi dalam satu wadah Desa untuk mencegah adanya persaingan tidak sehat, tapi sebaliknya mampu menumbuhkan perekonomian bersamaan tumbuhnya kebersamaan sebagai cerminan corak komunal religius dari hukum adat itu sendiri.

Sistem tata kelola yang selama ini masih dilaksakan secara tradisional, dapat diadaptasi dan mengadaptasi dengan sistem administrasi modern berbasis IT yang berorintasi pada asas manfaat tanpa meninggalkan dan menghilangkan jati diri, seperti kejujuran, kebersamaan, keterbukaan, dokumen administrasi (arsip)/pembukuan, kewenangan, tidak bertentangan dengan hukum Negara.

Bagaimana penguatan di bidang pertanahan, yaitu dalam penguasaan dan pengelolaan tanah adat/tanah (hak) ulayat sebagai druwe desa...?

a. Terhadap tanah-tanah adat seperti Laba Pura sejak tahini 1986 sudah dapat disertipiakatkan atas nama Pura (Tri Mandala) termasuk di dalamnnya tanah Setra, yaitu mengikuti Keputusan Menteri Dalam negeri No: SK.556/DJA/1986.

b. Mengembalikan fungsi tanah adat di bawah penguasaan dan pengelolaan Desa Adat (telajakan, garase, warung, sempadan jalan, sempadan got atau sungai sebagai penciri desa adat yang hanya dpat dijumpai di Bali, walaupun dibentuk 10 Bali baru di Indonesia atau di dunia (aspek komunal religius yang tidak dapat diciptakan di tempat lain)

c. Melakukan inventarisasi terhadap semua bidang tanah adat yang dikusasi krama untuk dicatat dan didaftar dalam Peta Dasar Pendaftaran tanah, atau diterbitkan sertipikat Hak Pakai di atas
HPL/Hak Milik (Komunal) Desa Adat. Sementara untuk tanah Banjar dapat disertipiakatkan atas nama Pura (Penyarikan) Banjar, atau sertipikat Hak Pakai Banjar di atas HPL/Hak Milik (Komunal) Desa Adat. Sementara untuk Tanah (Hak) Ulayat lain dapat didaftarkan dalam Peta Dasar Pendaftaran Tanah. Jadi Sertifikasi terhadap tanah-tanah adat disesuaikan dengan jenis, fungsi, dan penguasaannya yang berorientasi pada pelestarian "ayahan".

d. Penguatan hak penguasaan Desa Adat terhadap pengelolaan sebagai kesatuan Hak Ulayat (Prabumian).

\section{Simpulan dan Rekomendasi}

Sampai saat ini penguasaan hak atas tanah (hak) ulayat (tanah adat) yang dilakukan secara individual dan komunal dalam perspektif UUPA masih gamang atau kabur karena di satu sisi dapat menguatkan penguatan terhadap penguasaan individu dan melepaskan dengan ikatan ayahanmya, dan di sisi lain tidak adanya kepastian data fisik dan data yuridis perspektif hukum Negara. Implikasi lebih lanjut adalah timbulnya kerancauan dalam pendaftarannya terlebih dengan adanya program PTSL dan penunjukan Desa Adat sebagai Subjek Hak Pemilikan Bersama (Komunal ) Atas Tanah, karena telah disikapi secara beragam oleh Desa Adat dan BPN dalam sertipikasinya.

Dalam kondisi ini perlu direkomendasikan, bahwa BPN sebagai struktur hukum yang diberikan kewenangan dalam upaya pelaksanaan percepatan PTSL agar dapat bertindak cermat dan mampu memberikan kepastian hukum, keadilan, dan kemanfaatan terhadap pelaksanaan kebijakan sertifikasi tanah-tanah adat secara proporsional dan professional, bukan berorientsi pada target capaian, sehingga tanah-tanah adat dapat dimanfaatkan dan digunakan sesuai dengan 
fungsinya dan perkembangan kebutuhan masyaraktnya. Demikian pula Desa Adat tidak serta merta dapat memberi tafsir bahwa seluruh tanah adat wajib didaftar untuk disertifikasi dengan titel "Hak Milik", karena Hak Milik Komunal dengan Hak Ulayat sangat berbeda. Tapi tidak menafikan pendaftarannya, karena diharapkan ada koeksistensi antara hukum adat dengan hukum Negara dalam pendaftaran tanah-tanah adat.

\section{References}

\section{Buku Teks, Publikasi dan Dokumentasi} Ilmiah

[1]Sastrawan, I. P. D., Guntur, I. G. N., \& Andari, D. W. T. (2018). Urgensi Penguatan Hak atas Tanah Druwe Desa di Bali. Jurnal Tunas Agraria, 1(1 Sept).

[2]Suwitra, I. M. (2010). Konsep Komunal Religius Sebagai Bahan Utama dalam Pembentukan UUPA dan Dampaknya Terhadap Penguasaan Tanah Adat di Bali. Perspektif, 15(2), 174-194.

[3]Suwitra, I Made, 2014, "Penguasaan Hak Atas Tanah dan Masalahnya", Makalah, disampaikan dalam rangka bimbingan teknis (Bintek) aparatur pemerintahan desa dan kecamatan se Kota Denpasar, tanggal 6 Mei 2014 di Denpasar.

[4]Suwitra, I. M. (2010). Dampak Konversi Dalam UUPA Terhadap Status Tanah Adat di Bali. Jurnal Fakultas Hukum UII, 17(1), 103-118.

[5]Suwitra, I. M. (2018). Larangan Pengasingan Tanah dalam Hukum Adat Perspektif Hukum Agraria Nasional. Jurnal Yustika: Media Hukum dan Keadilan, 14(1), 39-51.

[6]Bali Post, "Konflik adat", Denpasar, 27 September 2011., hlm. 1-20.
[7]Bali Post, "Budaya anarkis", Denpasar, 12 Agustus 2009, hlm. 1-20.

[8]Suwitra, I. M., \& Puspadma, I. N. A. (2018, November). Legal Certainty Perspective on Ulayat Land Ownership in Bali. In International Conference on Business Law and Local Wisdom in Tourism (ICBLT 2018). Atlantis Press.

[9]Peter Mahmud Marzuki,. 2005. Penelitian Hukum, Cetakan I. Fajar Interpratama, Surabaya.

[10]Johnny Ibrahim. 2006. Teori \& Metodologi Penelitian Hukum Normatif. Edisi Revisi. Cetakan Kedua. Bayumedia Publishing, Malang Jawa Timur.

[11]Surojo Wignjodipuro. 1979. Pengantar dan Asas-Asas Hukum Adat, Edisi ke tiga. Alumni, Bandung.

[12]Salinan Pemuder Desa Adat Culik Karangasem, 1922.

[13]K. Wantjik Saleh. 1979. Hak Anda Atas Tanah, Ghalia Indonesia. Jakarta.

[14]Suastawa Dharmayuda. 1987. Status dan Fungsi Tanah Adat Bali Setelah Berlakunya UUPA. Cetakan I. CV Kayu Mas. Denpasar.

[15]Valerine Jaqueline Leonore Kriekhoff. 1991. "Kedudukan Tanah Dati sebagai tanah adat di Maluku Tengah, suatu kajian dengan memanfaatkan pendekatan antropologi hukum". Disertasi. Program Doktor Ilmu Hukum Fakultas Pasca Sarjana Universitas Indonesia.

[16]Urip Santoso. 2006. Hukum Agraria, HakHak Atas Tanah, Cetakan Kedua. Prenada Media. Jakarta. 
[17]Leopold Pospisil. 1971. Anthropology of Law a Comparative Theory. Harper \& Raw Publishers. New York, Evanston, San Francisco, London.

[18]Herman Soesang Obeng, 1975. Pertumbuhan hak milik individuil menurut hukum adat dan menurut UUPA di Jawa Timur. Majalah Hukum. II (3): 49-76.

[19]Sonny Keraf. A, 1997, Hukum Kodrat \& Teori Hak Milik Pribadi, Kanisius, Yogjakarta.

[20]Maria S.W. Sumardjono. 2005. Kebijakan Pertanahan antara Regulasi \& Implementasi, Edisi Revisi. Buku Kompas. Jakarta.

[21]Martua Sirait, Chip Fay, dan A.Kusworo. 2001. "Bagaimana hak-hak Masyarakat Adat dalam Mengelola Sumber Daya Alam Diatur ". Dalam Kajian Kebijakan Hak-Hak Masyarakat Adat di Indonesia Daerah.; suatu Refleksi Pengaturan Kebijakan dalam Era Otonomi Daerah. ICRAF, Lembaga Alam Tropika Indonesia, dan P3AE-UI.

[22]Setorus, Oloan. 2004. Kapita Selekta Perbandingan Hukum Tanah, Cetakan Perdana. Mitra Kebijakan Tanah Indone. Yogyakarta.

[23]Achmad Sodiki, 2004. "Eksistensi hukum adat: Konseptualisasi, Politik hukum dan pengembangan pemikiran hukum sebagai upaya perlindungan hak masyarakat adat. Makalah. disampaikan dalam seminar Fakultas Hukum Universitas Brawijaya Malang.

[24]Suastawa Dharmayuda, Made. 1987. Status dan Fungsi Tanah Adat Bali
Setelah Berlakunya UUPA, Cetakan I. CV Kayu Mas. Denpasar.

[25]Iman Sudiyat. 1981. Hukum Adat Sketsa Asas. Cetakan Kedua. Liberty. Yogyakarta.

[26]Suwitra, I Made. (2009). "Eksistensi Hak Penguasaan dan Pemilikan Atas Tanah Adat di Bali dalam Perspektif Hukum Agraria Nasional", (Doctoral dissertation, Universitas Brawijaya), Malang.

[27]R. Van Dijk. 1971. Pengantar Hukum Adat Indonesia. Terjem. A. Soehardi. Cetakan Ke Tujuh. Sumur Bandung. Jakarta.

[28]I Made Suwitra. 2005. "Tugas Prajuru Adat dalam mengatur tanah adat khususnya tanah telajakan dalam konsep menuju Bali yang ajeg". Kertha Wicaksana. Fakultas Hukum Universitas Warmadewa. Denpasar. (11) 1 .

\section{Peraturan Perundang-Undangan}

Undang-Undang Nomor 5 Tahun 1960 tentang Peraturan Dasar Pokok-Pokok Agraria.

Peraturan Pemerintah No.38 Tahun 1963 tentang Penunjukan Badan-Badan Hukum yang dapat mempunyai Hak Milik Atas Tanah.

Peraturan Pemerintah Nomor 24 Tahun 1997 tentang Pendaftaran Tanah.

Instruksi Presiden Nomor 2 Tahun 2018 tentang Percepatan Pendaftaran Tanah Sistematis Lengkap di Seluruh Wilayah Republik Indonesia;

Peraturan Menteri Agraria dan Tata Ruang/Kepala BPN RI Nomor 6 Tahun 2018 tentang Pendaftaran Tanah Sistematik Lengkap (PTSL). 
https://ejournal.warmadewa.ac.id/index.php/wicaksana

Keputusan Menteri Dalam Negeri Nomor: 189

Tahun 1981 Tentang Proyek Operasi Nasional Agraria.
Peraturan Daerah Propinsi Bali Nomor 3 Tahun 2001 Jo Nomor 3 Tahun 2003 tentang Desa Pakraman. 